\title{
Scripta
}

Revista Internacional de Literatura i Cultura Medieval i Moderna

\section{Pour la fête de notre séraphique mère sainte Thérèse: \\ A Teresian Celebration in Verse, and a Concise View of French Carmelite Poetry}

\section{Pour la fête de notre séraphique mère sainte Thérèse: Una celebració teresiana en vers i una breu ullada a la poesia carmelitana francesa}

\author{
Daniel Hanna \\ hanna@lakeforest.edu \\ Lake Forest College
}

\begin{abstract}
This article commemorating the 500th anniversary of the birth of Teresa of Avila has two purposes: one, the presentation and analysis of a newly discovered poem composed in honor or Teresa of Avila in the French Carmelite convent of Saint-Denis (Paris) and two, a brief overview of recent scholarly work on French Carmelite poetry. It is proposed in the article that the poems of Teresa of Avila, not always considered important in their own right, should be re-considered and re-contextualized as foundational texts in a long tradition of Carmelite poetry that is both international and multilingual.
\end{abstract}

Keywords: Teresa of Avila, poetry, Spain, France, manuscripts

Resum: Aquest article commemoratiu del 500 aniversari del naixement de Teresa d'Àvila té dos propòsits: el primer, la presentació i l'anàlisi d'un poema acabat de descobrir i fet en honor de Teresa d'Àvila al convent carmelità francés de Saint-Denis (París) i, en segon lloc, una breu descripció del treball acadèmic recent sobre la poesia carmelitana francesa. Es proposa a l'article que els poemes de Teresa d'Àvila, no sempre considerats importants per dret propi, s'han de tornar a considerar i recontextualitzar com textos fundacionals d'una llarga tradició de la poesia dels carmelitans, que és, alhora, internacional i multilingüe.

Paraules clau: Teresa d'Àvila, poesia, Espanya, França, manuscrits 
Daniel Hanna. Pour la fête de notre séraphique mère sainte Thérèse: A Teresian Celebration in Verse, and a Concise View of French Carmelite Poetry

As we celebrate the $500^{\text {th }}$ anniversary of the birth of Teresa Sánchez de Cepeda y Ahumada, we have occasion to reflect on the attention that has been dedicated to different aspects of her life and writings in the time since she became Teresa of Avila, and later Saint Teresa of Avila. The massive published corpus of works both by and about Teresa, neither necessary nor possible to list here, attests to the intense and growing interest, both popular and scholarly, in her life and work as a cloistered woman religious, a reformer, and an author. This article takes as its point of departure and contextual framework a facet of Teresa's life and work that has received relatively little attention, namely the practice of composing and sharing poems in the convents that she founded. ${ }^{1}$ This study will then take as its principal focus the continuation of this Teresian poetic tradition in France, and in so doing provide a brief view of some recent scholarly work on French Carmelite poetry. As a means of doing this that is at once a recognition of the Teresian celebration in which we currently engage and also a representative sample of the Teresian poetic tradition as it existed in France, a previously unstudied and unpublished manuscript poem from the archives of the Carmelite convent of Saint-Denis (Paris) will be presented here, and this poem will serve as a concise guide to the principal Teresian themes that appear in the verse compositions of the French Carmelites who followed in their founding mother's footsteps as the Discalced Carmelite Order expanded from Spain into France beginning in the early $17^{\text {th }}$ century. ${ }^{2}$ At the same time, the presentation and analysis of this «new》 poem will provide an opportunity to summarize some recent research and publication on French Carmelite poetry in general.

\section{Pour la fête de notre séraphique mère}

It is known from Teresa's letters that she viewed the composition of verse as an important activity in the convents that she had established in Spain, and in a letter written by the Spanish Carmelite

1 It is important to note that scholars of Spanish literature have in fact paid some attention to Teresa's poems, even if these studies are few in number compared to those on her prose and on her spirituality in general. See in particular Víctor García de la Concha, El arte literario de Santa Teresa, 317-376. It is also important to point out the studies that have been produced on the poetic production of other Spanish Carmelites, in particular edition of the Libro de romances y coplas del Carmelo de Valladolid (c. 1590-1609), ed. Victor García de la Concha and Ana María Álvarez Pellitero, 2 vols (Salamanca: Consejo General de Castilla y León, 1982). See also Ana María Álvarez Pellitero, 'Cancionero del Carmelo de Medina del Campo’, in Congreso Internacional Teresiano, 4-7 octubre, 1982, ed. Teófanes Egido Martínez, Víctor García de la Concha, and Olegario González de Cardedal, 2 vols. (Salamanca: Universidad de Salamanca, 1983), II, 525-43. Also important is María del Pilar Manero Sorolla's study of the poetry of María de San José, Exilios y Destierros en la Vida y en la Obra de María de Salazár, http://www.cervantesvirtual.com/FichaAutor.html?Ref=9721. Finally, no survey of Spanish Carmelite convent poetry is complete without Stacey Schlau and Electa Arenal's Untold Sisters: Hispanic Nuns in Their Own Works. Translations by Amanda Powell. Albuquerque: University of New Mexico Press, 1989.

2 For an overview of the expansion of Teresian Carmel into France, see Concha Torres Sánchez, La clausura imposible (Madrid: Asociación Cultural Al-Mudayna, 2000), in particular section 2, 'La expansión europea del Carmelo descalzo español (1600-1650)'.

SCRIPTA, Revista internacional de literatura i cultura medieval i moderna, núm. 6 / desembre 2015 / pp. 166 - 175 ISSN: 2340-4841 · doi:10.7203/SCRIPTA.6.7226 
Daniel Hanna. Pour la fête de notre séraphique mère sainte Thérèse: A Teresian Celebration in Verse, and a Concise View of French Carmelite Poetry

Isabel de los Angeles, who had traveled to France from Spain with Ana de Jesús and Ana de San Bartolomé, Isabel suggests that the novices in the new Carmelite convents that had been founded in France may have been taught the Teresian tradition. ${ }^{3}$ Writing from France to one of her Carmelite sisters back in Spain, Isabel wrote:

\footnotetext{
Bien me consolaría que me enviase mi Madre las [coplas] de «Andando el corazón buscando un día... y su cántico que hará mi Madre a la Pascua de Navidad. Mis hijas las hacen bien para nos dar recreación. Si mi madre las pudiera entender en su francés, yo sé bien tuviera buena recreación... 4
}

Here Isabel de los Angeles seems to confirm that poems (coplas) were sent from Spain to France (and perhaps vice versa) and also that her own French «daughters》 had taken up the Teresian tradition. Manuscripts that have been located in French convent archives in recent years also corroborate this. The archives of the Carmelite convent of Pontoise, France (some 30 kilometers northwest of Paris) are one of the richest repositories of French Carmelite verse, containing multiple bound volumes of manuscript poems composed by Carmelite women in the years following the arrival of Teresian Carmel in France. Among these poems, one composed in the convent of Saint-Denis, «Pour la fête de notre séraphique mère sainte Thérèse», celebrates not the anniversary of Teresa's March 28 birth as we do in 2015, but rather her feast day, October 15. The poem is undated, and as such it is not known in what year this celebration in Saint-Denis took place, but the poem's title make the occasion clear, and as will be seen in the presentation of the text, French Carmelites honored Teresa fully aware of key experiences in the spiritual life of their founding mother, and they strove to follow Teresa's example and to live by some of her most famous words.

In the opening stanza of the poem, the author addresses herself to the «grand séraphin》 that pierced Teresa's heart with a flaming arrow, evoking what is possibly the quintessential Teresian image:

\footnotetext{
Grand séraphin, dont le dard tout de braise

Fit autrefois une plaie d'amour,

Dans le beau cœur de l'illustre Thérèse :

Découvrez-nous ce trésor en ce jour.
}

Teresa recounted the experience of being wounded by the cherub's arrow in chapter 29 of her Libro de la vida:

\footnotetext{
3 See Teresa's letter of February 1 1580, to María de San José (Obras completas, 1257) and her letter of November 1 1581, also to María de san José (Obras completas, 1352).

4 Isabel, de A, and Pierre Sérouet. Une carmélite espagnole en France: cent cinq lettres inédites adressées aux Carmélites de Salamanque, 1606-1644. Paris: s.n., 1956, letter 75.
} 


\section{Daniel Hanna. Pour la fête de notre séraphique mère sainte Thérèse: A Teresian Celebration in Verse, and a Concise View of French Carmelite Poetry}

Víale en las manos un dardo de oro largo, y al fin de el hierro me parecía tener un poco de fuego; éste me parecía meter por el corazón algunas veces y que me llegava a las entrañas. Al sacarle, me parecía las llevava consigo, y me dejava toda abrasada en amor grande de Dios. (Teresa de Ávila, Obras completas, 158)

She also recalled the same experience in her poem «Mi amado para mí»:

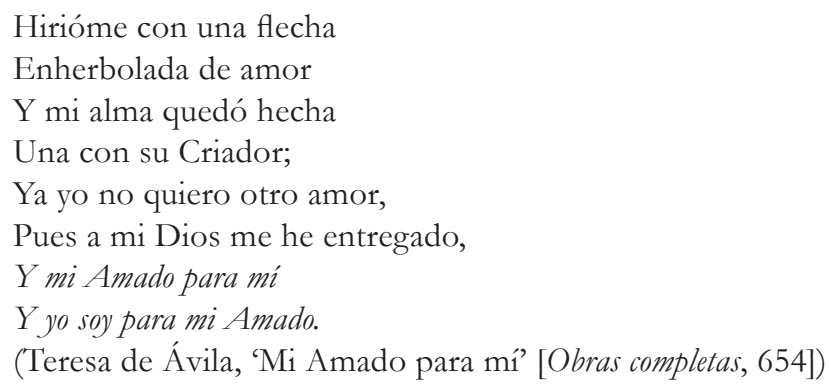

The theme of the Teresian arrow was a frequent one in the poems of French Carmelites; this can be seen in the first stanza of the poem «Pour la fête de notre séraphique mère sainte Thérèse» from Saint-Denis cited above, and also in other poems, including two from the archives of the convent of Beaune (Burgundy) $)^{5}$ :

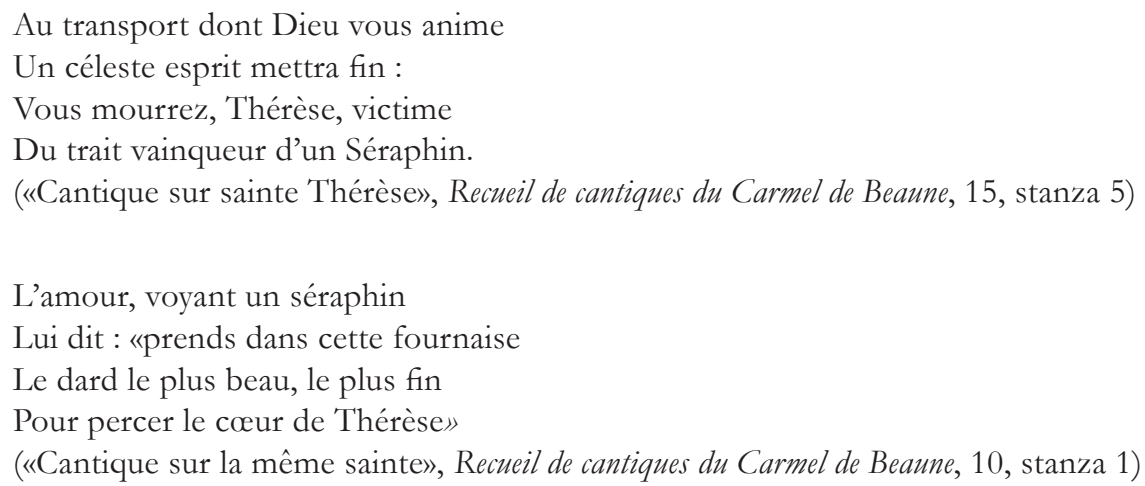

In a recent article, «Un trait thérésien: French Carmelite Poetry in the Tradition of Teresa of Avila》 (The Bulletin of Spanish Studies), Daniel Hanna presents and analyzes the two poems from Beaune cited above, along with others that demonstrate the vigorous continuity of the Teresian poetic

\footnotetext{
5 The Carmelite convent of Beaune having been closed in 2001, the majority of the convent's archives were transferred to the Municipal Archives of the City of Beaune. The poems cited here are found in a bound volume of manuscript poems currently housed in the Beaune Municipal Archives.
} 
Daniel Hanna. Pour la fête de notre séraphique mère sainte Thérèse: A Teresian Celebration in Verse, and a Concise View of French Carmelite Poetry

tradition in France. The Beaune poems, composed for the most part in the $17^{\text {th }}$ century, appear to be the earliest known examples of French Carmelite poetry, and as such have an important place in the larger study of the continuity of the Teresian poetic tradition. The vitality of this tradition and the important influence of the Teresian arrow are also in evidence in the poetry of Marie-Aimée de Jésus (1839-1874), a Parisian Carmelite who in one poem equated the power of the Teresian arrow with that of the name of Jesus:

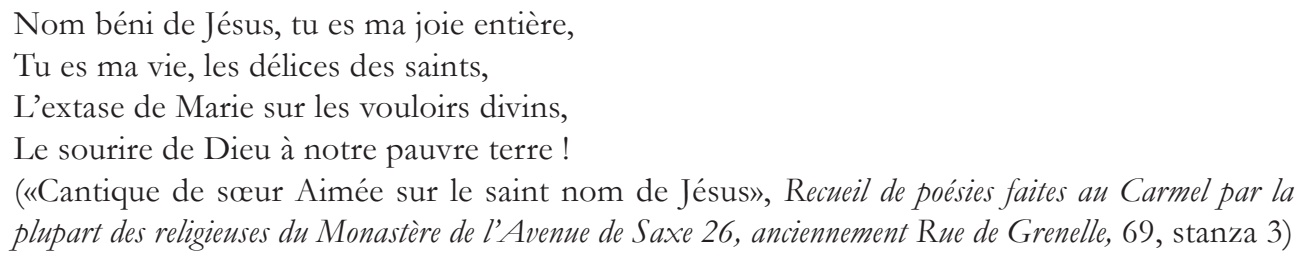

In the article «Defending Divinity: A Teresian Carmelite Responds to Ernest Renan's Vie de Jésus» (Women in French Studies), Hanna presents this and other poems composed by Marie-Aimée de Jésus, and demonstrates her use of the parallel forms of prose and poetry (similarly used by Teresa of Avila) in defense of the divinity of Christ against the «attack» made upon it by Ernest Renan in his Vie de Jésus. Marie-Aimée's poetry is significantly informed by both the prose and the poetry of Teresa of Avila, and as was the case for her sisters in the convents of Saint-Denis and Beaune, for Marie-Aimée the Teresian arrow did not fail to make its mark on her poetry.

\section{Teresian Raptures and the Flight of the Spirit}

In the second and third stanzas of the poem «Pour la fête de notre séraphique mère» from SaintDenis, the author continues her entreaty to the Teresian cherub, and evokes another well-known Teresian theme, that of raptures:

\footnotetext{
Exposez-nous la lumière très pure

Dont son esprit était toujours brillant,

Qui l'élevait par-dessus la nature,

Connaissant Dieu, et son propre néant.

En unissant l'amour à la science,

Que de transports, quel doux ravissement,

En saints désirs son cœur était immense :

Elle mourait d'amour à chaque instant.
}

In chapter 19 of her Libro de la vida, Teresa wrote of her elevations and raptures, and equated them to what she called the «flight of the spirit»: 
Daniel Hanna. Pour la fête de notre séraphique mère sainte Thérèse: A Teresian Celebration in Verse, and a Concise View of French Carmelite Poetry

Querría saber declarar con el favor de Dios la diferencia que hay de unión a arrobamiento u elevamiento, u vuelo que llaman de espíritu u arrebatamiento, que todo es uno. Digo que estos diferentes nombres todo es una cosa, y también se llama éstasi.

(Teresa de Ávila, Obras completas, 108)

Another poem from the aforementioned archives of Beaune, entitled «Vol d'esprit sur le mystère de la sainte Trinité», seems to echo Teresa's conception of raptures as a flight of the spirit: the influence of Teresa's vuelo and also that of the cherub's arrow are present in the poem's first stanza, where the two Teresian themes are joined:

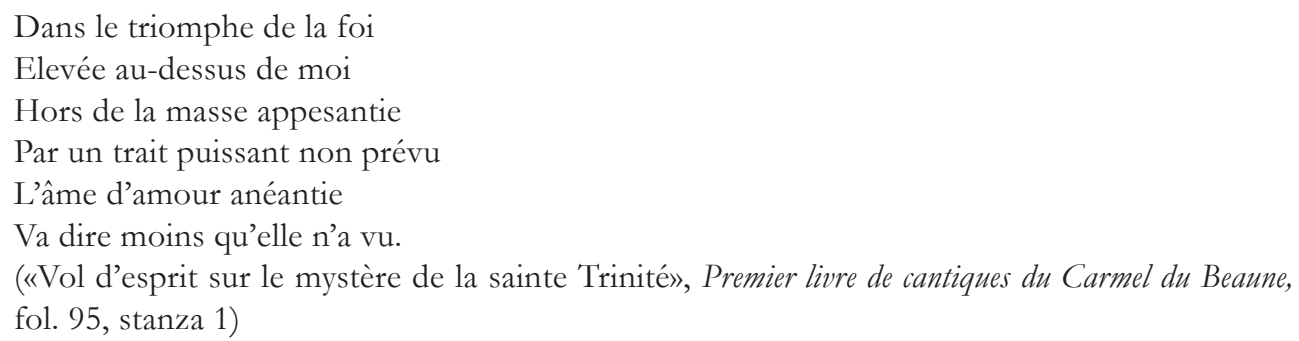

Like the theme of the Teresian arrow, that of the spirit in flight, transported in rapture toward union with God, is clearly present in the poems cited above from Beaune and Saint-Denis. Thematically, then, French Carmelites sought to instill their poetry with a Teresian presence which appears to be drawn from both the prose and the poetry of their founding mother, as they engaged in the «family tradition» of composing verse. The conclusion of the poem from Saint-Denis celebrating Teresa's feast day shows that French Carmelites also sought to live as Teresa did, and to follow her most famous maxim.

\section{Aut pati, aut mori}

In the fourth stanza of «Pour la fête de notre séraphique mère sainte Thérèse«, the author adopts the voice of Teresa, praying to Christ:

»O mon Jésus, dit-elle, je me pâme,

Je veux souffrir pour vous ou bien mourir.

Donnez, donnez ce plaisir à mon âme :

L'amour le veut, ou souffrir ou mourir».

The phrase Ou souffrir ou mourir, in Spanish O sufrir o morir, in Latin Autpati, aut mori, is often attributed to Teresa as a concise formulation of her wishes to either suffer for God or to die for God. Clearly echoed in the fourth stanza of the poem from Saint-Denis cited above, this expression also forms the foundation of another French Carmelite poem, this one unattributed but from the same convent where Marie-Aimée de Jésus lived, on the Avenue de Saxe in Paris: 
Daniel Hanna. Pour la fête de notre séraphique mère sainte Thérèse: A Teresian Celebration in Verse, and a Concise View of French Carmelite Poetry

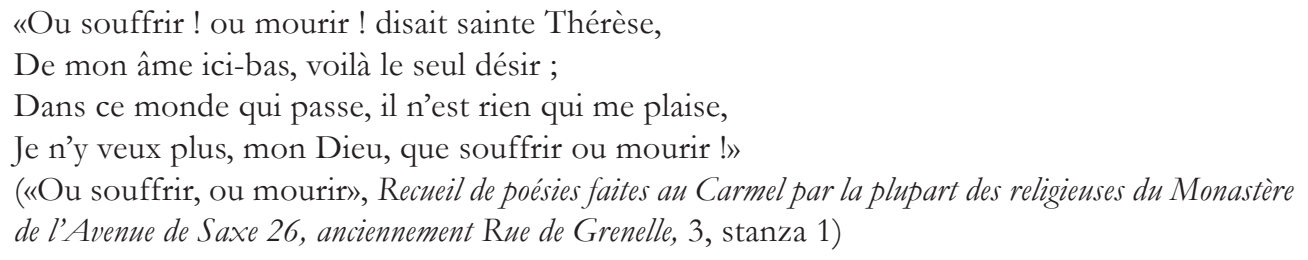

In the fifth stanza of the poem from Saint-Denis, the author sustains Teresa's plea, highlighting the essential difference between Christ and the one who prays to Him:

《Quoi, vous aimer sans vous être semblable?

Divin Jésus, je ne le puis souffrir.

La croix, la croix, j'en suis insatiable :

Je veux toujours souffrir ou bien mourir !》

The suffering expressed in this stanza that comes from being so different from God is perhaps an echo of Teresa of Avila's poem «Hermosura de Dios》, in which she wrote of a knot that binds together two things of different natures:

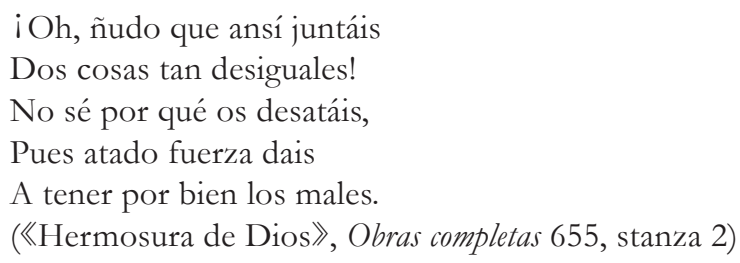

In Jésus-Christ est le Fils de Dieu, the prose treatise in which Marie-Aimée de Jésus responded to Ernest Renan's Vie de Jésus, the French Carmelite cited this same passage of Teresa's poem (in French translation) as part of her argument against Renan's assertion that Jesus was only human; using Teresa's poem as support, she countered that Jesus was both human and divine:

\footnotetext{
Qu'il est puissant ce nœud qui joint ensemble

Les deux objets les moins faits pour s'unir, Tant que ce nœud, par vos soins les assemble, Les plus grands maux se changent en plaisir! (Jésus-Christ est le Fils de Dieu, Tome I, 62)
}

For the author of the poem «Pour la fête de notre séraphique mère sainte Thérèse» from SaintDenis, the Teresian «knot» may have been a source of inspiration in an original poem; in the writings of Marie-Aimée de Jésus, the force of Teresa's metaphor is felt just as strongly, but this time in the form of a direct citation, emphasizing the importance of Teresa's poem for the French Carmelite author who wrote in defense of Christ's divine nature. 
Daniel Hanna. Pour la fête de notre séraphique mère sainte Thérèse: A Teresian Celebration in Verse, and a Concise View of French Carmelite Poetry

In the closing stanzas of the poem from Saint-Denis, the author addresses herself directly to the community, now maintaining «ou souffrir ou morin» as a sort of refrain, and also an ideal to be emulated:

\footnotetext{
Chères enfants, vous serez légitimes

Si vous sentez en vous ce saint désir :

De votre mère embrassez les maximes,

Dites comme elle : «ou souffrir ou mourir».

$\mathrm{Ne}$ cherchez point de gout ni de lumière,

En ce seul point mettez votre plaisir ;

Du fond du cœur faites cette prière :

«Pour vous, Jésus, ou souffrir ou mourir».

Chaque vertu dans ce point est comprise ;

Si vous voulez bientôt vous enrichir,

Apprenez pour vous cette même devise,

Dites toujours : «ou souffrir ou mourir».
}

In another recent article, «The Poetic Habit: Verse and Vestment in Spanish and French Carmel» (Early Modern Women: An Interdisciplinary Journal), Daniel Hanna demonstrates that both Spanish and French Carmelites used their poetry to extoll the virtues of their religious dress, and in one of the poems presented in «The Poetic Habit», this time from the Carmelite convent on Rue de Grenelle in Paris, the author exhorts a novice who is receiving the habit (sister «Thaïs») to not only dress as Teresa did, but also to live as she had lived:

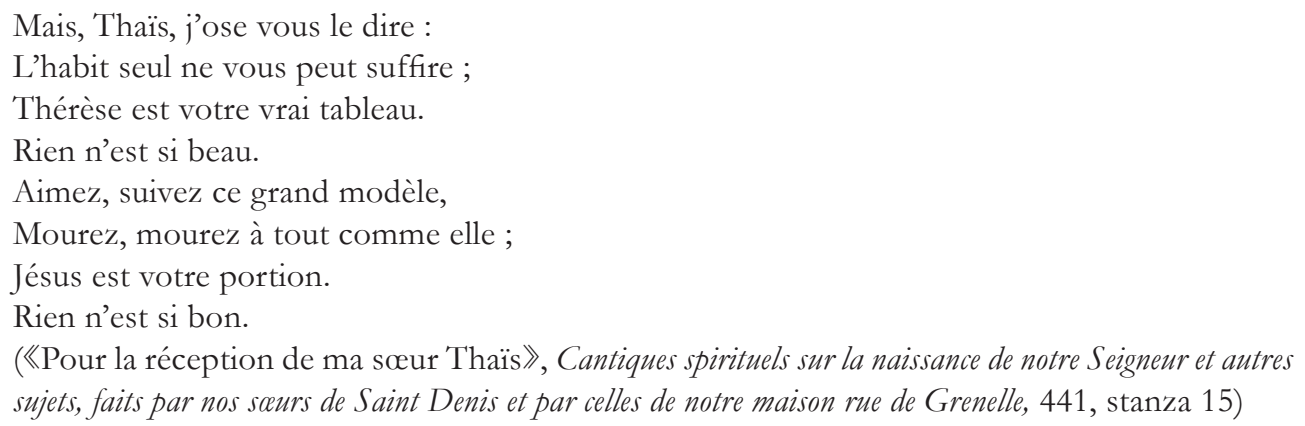

Here the importance of imitating not just the sartorial model of Teresa of Avila, but also (and most importantly) her spiritual model, is clear. Like the author of «Pour la fête de notre séraphique mère sainte Thérèse», who insists that Carmelites must live by Teresa's famous slogan that leaves suffering or death as the only acceptable options, the author of «Pour la réception de ma sœur Thaïs》 also stresses that the Carmelite who receives the habit must «die to everything》 (mourez à tout) as Teresa had done. These poems make abundantly clear that for the French Carmelites who so actively maintained Teresian traditions of verse and vestments, the most important Teresian tradition was the spiritual one, according to which a good Carmelite could only suffer or die for the glory of God. 
Daniel Hanna. Pour la fête de notre séraphique mère sainte Thérèse: A Teresian Celebration in Verse, and a Concise View of French Carmelite Poetry

\section{Conclusions}

In concluding, I would like to propose that we think anew about the poems of Teresa of Avila, and consider the larger and longer tradition to which they appear to have given rise. Taken together, Teresa's poems, the poems of her Spanish Carmelite followers, and now the poems of her French «daughters» form an international and multilingual corpus that spans at least three centuries. Given this, I believe that it is reasonable to consider, and indeed to re-read, Teresa's verse compositions as «founding poems» in the literature of the Discalced Carmelite Order, just as Teresa herself was the founding leader of that order. Clearly inspired by Teresa's example as a poet and also by her writings generally, French Carmelites, like their Spanish sisters before them, carried on a tradition that, like the memory of Teresa we celebrate today, lived on long after her time. 
Daniel Hanna. Pour la fête de notre séraphique mère sainte Thérèse: A Teresian Celebration in Verse, and a Concise View of French Carmelite Poetry

\section{Bibliografía}

Álvarez Pellitero, Ana María (1983) «Cancionero del Carmelo de Medina del Campo», in Congreso Internacional Teresiano, 4-7 octubre, 1982, ed. Teófanes Egido Martínez, Víctor García de la Concha, and Olegario González de Cardedal, 2 vols., Salamanca: Universidad de Salamanca, II, 525-43.

Arenal, Electa, and Stacey Schlau (1989) Untold Sisters: Hispanic Nuns in Their Own Works, Translations by Amanda Powell. Albuquerque, University of New Mexico Press.

García de la Concha, Víctor (1978) El arte literario de Santa Teresa, Ariel, Letras e Ideas : Maior, 13.

García de la Concha, Víctor, and Ana María Álvarez Pellitero, eds. (1982) Libro de romances y coplas del Carmelo De Valladolid (c. 1590-1609), 2 vols., Salamanca, Consejo General de Castilla y Leon.

Hanna, Daniel J. (2015) «The Poetic Habit: Verse and Vestment in Spanish and French Carmel», Early Modern Women: An Interdisciplinary Journal, Vol. 9, no. 2.

- (2015) «Un trait thérésien: French Carmelite Poetry in the Tradition of Teresa of Avila», The Bulletin of Spanish Studies, forthcoming.

—_. (2015) «Defending Divinity: A Teresian Carmelite Responds to Ernest Renan's Vie de Jésus, Women in French Studies, forthcoming.

Isabel, de A, and Pierre Sérouet (1956) Une carmélite espagnole en France: cent cinq lettres inédites adressées aux Carmélites de Salamanque, 1606-1644, Paris.

Manero Sorolla, María Pilar (2006) «Exilios y destierros en la vida y en la obra de María de Salazar», in Anuario de la Sociedad Española de Literatura General y Comparada, VI-VII (1988-89), 51-59, http://www.cervantesvirtual.com/obra/exilios-y-destierros-en-la-vida-y-en-la-obra-de-marade-salazar-0/

—. (2007) «Un diálogo de carmelitas primitivo traducido al francés: Pour L'instruction de novices de María De San José (Salazar)», in Traducción y adaptación cultural: España-Francia, ed. M ${ }^{a}$ Luisa Donaire and Francisco Lafarga, Oviedo, Univ. de Oviedo, 369-79, http://www.cervantesvirtual.com/obra/ un-dilogo-de-carmelitas-primitivo-traducido-al-francs--pour-linstruction-de-novices-de-marade-san-jos-salazar-0

Marie-Aimée de Jésus (1974) Jésus-Christ est le Fils de Dieu, 2 vols., Paris, P. Téqui.

«Pour la fête de notre séraphique mère sainte Thérèse», Archive of the Carmelite Convent of Pontoise, France.

Recueil de cantiques du Carmel de Beaune, Municipal Archives of the City of Beaune, France.

Recueil de poésies faites an Carmelpar la plupart des religieuses du Monastère de l'Avenue de Saxe 26, anciennement Rue de Grenelle, Archives of the convent of Créteil, France.

Teresa of Avila (2003) Obras completas, Ed. Efrén de la Madre de Dios and Otger Steggink, Madrid, Biblioteca de autores cristianos.

Torres Sánchez, Concha (2000) La clausura imposible, Madrid, Asociación Cultural Al-Mudayna. 